\title{
A SENSITIVE, COUPLED ASSAY FOR PLASMINOGEN ACTIVATOR USING A THIOL ESTER SUBSTRATE FOR PLASMIN *
}

\author{
Patrick L. Coleman and George D. J. Green $\dagger$ \\ Department of Human Genetics \\ University of Michigan Medical School \\ Ann Arbor, Michigan 48109 \\ $\dagger$ Biology Department \\ Brookhaven National Laboratory \\ Upton, New York 11973
}

\section{INTRODUCTION}

In parallel with the increased interest during the past decade in plasminogen activator involvement in fibrinolysis, tumorigenesis, inflammatory responses, and the expression of hormonal regulation, there has been a rising interest in sensitive and precise methods for the specific assay of plasminogen activator. Several assays for plasminogen activator employ a direct assay method. ${ }^{1-4}$ These are remarkably sensitive methods, yet they suffer in comparison to the sensitivity of coupled methods. ${ }^{5-7}$ Coupling the assay with plasminogen not only amplifies the sensitivity by the multiplicative effect of plasmin, but insures that only those proteases specific for plasminogen are assayed. The choice of substrate for plasmin is critical. In general, esters are superior to amides in both $K_{m}$ and $k_{c a t}$, but they suffer a major deficiency in that they are frequently unstable at $\mathrm{pH} 7-9$, the optimum range for plasmin. Green and Shaw ${ }^{8}$ synthesized a thiol ester substrate, thiobenzyl benzyloxycarbonyl-L-lysinate ( $Z$-Lys-SBzl), which combines high $k_{c a t}$ with alkaline stability relative to the commonly used esters.

In an effort to characterize the plasminogen activator from hepatoma tissue culture (HTC) and its hormonally controlled inhibitor, several of the known direct and coupled methods were found inadequate by reason of either low sensitivity or imprecision. Using $Z$-Lys-SBzl in a coupled approach we have developed an assay that is superior to the [ $\left.{ }^{125} I\right]$ fibrinolytic assay. It is also extremely sensitive to plasminogen activator $\left(\sim 2 \times 10^{-17}\right.$ moles of urokinase) and can be used for routine analysis of purification as well as kinetic and binding studies.

\section{Material and Methods}

\section{Methods}

Plasminogen was prepared from fresh frozen plasma by the method of Deutsch and Mertz. ${ }^{9}$ Purified plasminogen was exhaustively dialyzed against

* This work was supported by National Institutes of Health Grant CA 22729 to T. D. Gelehrter (Department of Human Genetics, University of Michigan (P.L.C.)) and the U.S. Department of Energy (G.D.J.G.). 
$1 \mathrm{mM} \mathrm{HCl}$, lyophilized, and stored at $-20^{\circ} \mathrm{C}$. Concentration was routinely determined by absorbance at $280 \mathrm{~nm} ; \mathrm{E}_{280 \mathrm{~nm}}{ }^{1 / \%}=17.0 .^{10}$ Plasmin, the gift of Dr. David Aronson, was subsequently exhaustively dialyzed against $1 \mathrm{mM} \mathrm{HCl}$ and stored at $-20^{\circ} \mathrm{C}$. Plasmin concentration was determined by active-site titrations using $p$-nitrophenyl-p-guanidinobenzoate. ${ }^{11}$ Urokinase concentration was determined by active-site titrations with methylumbelliferyl $p$-guanidinobenzoate, ${ }^{12,13}$ using a ratio fluorometer built by Dr. D. Ballou (Dept. of Biological Chemistry).

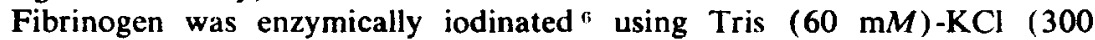
$\mathrm{m} M$ ) buffer, $\mathrm{pH}$ 7.6. Unbound iodide was separated by chromatography on Dowex $1\left(\mathrm{Cl}^{-}\right)$. Specific radioactivity was $9 \times 10^{11} \mathrm{cpm} / \mathrm{g}$. Fibrin plates were prepared and fibrinolysis continuous assays were performed as previously described. ${ }^{6}$ Discontinuous fibrinolysis assays were also performed, wherein plasminogen and urokinase were incubated in the absence of the fibrin, then added to the [125I]fibrin well.

Plasminogen activator and inhibitor were prepared from HTC cells as previously described ${ }^{14}$ except that serum-free conditioned medium additionally contained bovine serum albumin $(1 \mathrm{mg} / \mathrm{ml})$. HeLa-cell plasminogen activator was obtained as serum-frec conditioned îtedium."

Assay

The plasminogen-activator assay is a two-step procedure. In the first step plasminogen is activated to plasmin. The plasmin-catalyzed hydrolysis of Z-Lys-SBzl in the presence of 5,5'-dithiobis (2-nitrobenzoic acid) (DTNB) occurs in the second step. All reactions are typically performed in a 24-well tissue culture dish (each $15 \mathrm{~mm}$ diameter). This is not necessary, but convenient when handling many assays simultaneously.

The incubation mixture for the first step typically contains: plasminogen, $1.0 \mu M$; glycine, pH 8.50, $120 \mathrm{mM}$; bovine serum albumin, $0.5 \mathrm{mg} / \mathrm{ml}$; urokinase, $2.7 \times 10^{-12} M$. Total volume is $50 \mu \mathrm{l}$. The activity equivalent in plasminogen activator from HTC or HeLa cells may be substituted for urokinase. The reaction is started by the addition of plasminogen to the otherwise complete incubation mixture equilibrated at $37^{\circ} \mathrm{C}$. Normally this incubation is allowed to react for $\mathbf{4 5} \mathrm{min}$.

The second step is initiated by dilution of the incubation mixture with $950 \mu 1$ of the plasmin substrate solution: Z-Lys-SBzl, $200 \mu M$; DTNB $220 \mu M$; Triton X-100 0.01\%; sodium phosphate ( $\mathrm{pH} 7.50) 200 \mathrm{mM}$; sodium chloride, $200 \mathrm{mM}$. Normally the second step is quenched after $60 \mathrm{~min}$ by the addition of $100 \mu \mathrm{l}$ of soybean trypsin inhibitor $(1 \mathrm{mg} / \mathrm{ml}$ in $1 \mathrm{mM} \mathrm{HCl})$. The absorbance at $412 \mathrm{~nm}$ may be read immediately or up to $4 \mathrm{~h}$ later. The extinction coefficient of $14,150 \mathrm{~cm}^{-1} \cdot \mathrm{M}^{-1}$ was assumed for the thiophenolate product of the reaction of benzyl mercaptan with DTNB. ${ }^{15}$

Inhibitors were tested by incubation with the first-step incubation mixture prior to the addition of plasminogen. Bimolecular rate constants, $k_{a p p} /[I]$, were determined as previously described. ${ }^{16}$ Plasmin standard curves were obtained by substituting plasmin for plasminogen and urokinase in step one.

Other variations from the standard procedure were tested. $Z$-Lys-SBzl was substituted by $\mathrm{D}-\mathrm{Val} \cdot \mathrm{Leu} \cdot \mathrm{Lys}$ - -nitroanilide. 2,2'-dithiodipyridine and 4,4'dithiodipyridine, dissolved in dimethylformamide, were substituted on an equi- 
molar basis for DTNB. All absorbance measurements were performed on a Gilford spectrophotometer model 2400-2.

\section{Material}

Fibrinogen (plasminogen-free), urokinase (B grade) and DTNB were the products of Calbiochem-Behring (La Jolla, CA). 2,2'- and 4,4'-dithiodipyridine were obtained from Aldrich Chemical Co. (Milwaukee). Carrier-free [ $\left.{ }^{125} \mathrm{I}\right]$ (sodium salt) was purchased from Amersham-Searle (Chicago). D-Val-Leu Lys $p$-nitroanilide was purchased from Kabi Group (Greenwich, CT). Z-LysSBzl was synthesized by Peninsula Laboratories (San Carlos, CA) according to the procedure of Green and Shaw. ${ }^{8}$ Methylumbelliferyl $p$-guanidinobenzoate and soybean trypsin inhibitor (B grade) were obtained from Sigma Chemical Co. (St. Louis). Phe - Ala $\cdot \mathrm{ArgCH}_{2} \mathrm{Cl}$ was the gift of Dr. Elliott Shaw. All other chemicals were of reagent grade; 24-well culture plates were purchased from Linbro Co. (Bridgeport, CT).

\section{Results}

The sensitivity of the assay depends on the combination of a low "spontaneous" rate of $Z$-Lys-SBzl hydrolysis with a high enzyme rate. TABLE 1 presents results of a buffer survey in which sodium phosphate yielded both the highest plasmin-catalyzed rate and the lowest "spontaneous" rate. The effect of Triton X-100 (0.001\%-2\%) on plasmin activity was determined (data not shown). Optimal activity was broadly centered on $0.01 \%$ Triton X-100, which was $150 \%$ of the rate of the detergent-free control. There was no effect on the "spontaneous" rate. Sodium chloride has an inhibitory effect on urokinase and HeLa and HTC plasminogen activators, but below $250 \mathrm{mM}$ no effect was observed on plasmin activity (data not shown). Thus $200 \mathrm{mM} \mathrm{NaCl}$ was added to the plasmin assay solution, which depressed plasminogen activation $78 \%$. Figure 1 presents the time- and plasmin concentration-dependence of the reaction. The rates are linear at least two hours if the substrate is not depleted. Under these conditions $K_{m}$ is $19 \mu M, k_{\text {cat }}$ is $45 \mathrm{sec}^{-1}$.

Several modifications of the standard procedure were attempted in search of increased sensitivity (TABLE 2). The rate with $4,4^{\prime}$-dithiodipyridine was comparable to that with DTNB but the control (zero plasmin) absorbance was four-fold higher, thus limiting its utility at low enzyme levels. Doubling the substrates produced a $10 \%$ sensitivity gain, but with almost double the blank value.

Optimizations of the first step in the reaction (plasminogen activation) were performed by coupling these experiments to optimal plasmin assay conditions. Sodium glycinate gave the highest urokinase activity (TABLE 1). There was no effect of glycine concentration $(20-1600 \mathrm{mM})$ on urokinase rate nor any effect of Triton X-100 above that attributable to its effect on plasmin (data not shown). Figure 2 presents the time- and urokinase concentrationdependence of the reaction. Urokinase activity is not reproducibly linear beyond $45 \mathrm{~min}$, even in the absence of substrate depletion.

A direct comparison was made to a sensitive [ ${ }^{125}$ I] fibrin-lysis assay using either a continuous or discontinuous procedure (FIGURE 3 ). In the discon- 
tinuous assays, whether spectrophotometric or radiometric, the rate is directly proportional to the urokinase concentration, thus upward curvature would be expected on semi-log graph paper. In the continuous assays, both proteases are acting simultaneously (two amplifying mechanisms), thus, based on an analysis of the kinetic equations the response presented on semi-log paper should be linear. It is obvious that the spectrophotometric assay is significantly more sensitive than the radiometric assay.

The standard assay was used to evaluate $K_{m}$ and $k_{c a t}$ for the urokinasecatalyzed activation of plasminogen. $K_{m}$ and $k_{c a t}$ values were $1.7 \mu M$ and

TABLE 1

Effects of Various Buffers on Plasmin and UROKINASE ACTIVITY *

\begin{tabular}{|c|c|c|c|}
\hline \multirow[b]{3}{*}{ Buffer } & \multicolumn{3}{|c|}{$\begin{array}{l}\text { Relative Rates of Hydrolysis } \\
\text { (\% of Rate in Sodium } \\
\text { Phosphate) }\end{array}$} \\
\hline & \multicolumn{2}{|c|}{ Plasmin } & \multirow{2}{*}{$\frac{\text { Urokinase }}{\text { Enzymic }}$} \\
\hline & Enzymic & Non-enzymic & \\
\hline Phosphate (Na) & 100 & 100 & 100 \\
\hline MOPS + & 92 & 100 & 118 \\
\hline Barbital † & 93 & 250 & - \\
\hline Tris $t$ & 76 & 420 & 102 \\
\hline Glycine $\uparrow$ & 79 & 220 & 143 \\
\hline Triethanolamine $\dagger$ & 87 & 290 & 100 \\
\hline Tricine $\uparrow$ & 86 & 290 & 104 \\
\hline Pyrophosphate $\dagger$ & 75 & 120 & 69 \\
\hline Phosphate (K) $\ddagger$ & 82 & - & 100 \\
\hline HEPES * & 84 & - & 126 \\
\hline TES $\dagger$ & 92 & - & 116 \\
\hline
\end{tabular}

* All assays were performed at $37^{\circ} \mathrm{C}$. Plasmin activity was determined by continuous recording of $A_{118}$. Urokinase activity was determined by the standard plasminogen activation assay described herein. In each case the pH profile $(6.5-10)$ for sodium phosphate was obtained for comparison. The pH optima were: plasmin, 7.5; urokinase, 8.5-9.0. There was no variation in the blank rate in the urokinase assay. All buffers are $100 \mathrm{mM}$. pH was measured before and after incubation, and these values agreed \pm 0.05 ,

$\dagger$ pH 8.50.

$\ddagger$ pH 7.50.

$44 \mathrm{~min}^{-1}$, respectively, in $0.15 \mathrm{M} \mathrm{NaCl}$. These compare favorably with $1.7 \mu \mathrm{M}$ and $50 \mathrm{~min}^{-1}$ reported by Wohl et al. ${ }^{17}$ for the high molecular weight form of urokinase at $\mathrm{pH} 7.40,37^{\circ} \mathrm{C}$. The $K_{m}$ of the HeLa plasminogen activator was $1.8 \mu M ; V_{\text {mas }}$ was $0.16 \mathrm{ng}$ plasminogen activated $/ \mathrm{min} / \mathrm{ng}$ HeLa protein.

Inhibition of urokinase activity by $\mathrm{Phe} \cdot \mathrm{Ala} \cdot \mathrm{ArgCH}_{2} \mathrm{Cl}$ (FIgURE 4 ) and the dexamethasone-induced inhibitor from HTC cells (FIGURE 5) was also analyzed. The bimolecular rate constants $\left(k_{a p p} /[\mathrm{I}]\right)$ for the inactivation of urokinase by the chloromethyl ketone, whether determined by the coupled plasminogenactivation assay or by the direct urokinase-catalyzed hydrolysis of $Z$-Lys-SBzl $\left(26 \times 10^{3}\right.$ and $24 \times 10^{3} \mathrm{~min}^{-1} \cdot \mathrm{M}^{-1}$, respectively), are in close agreement. 


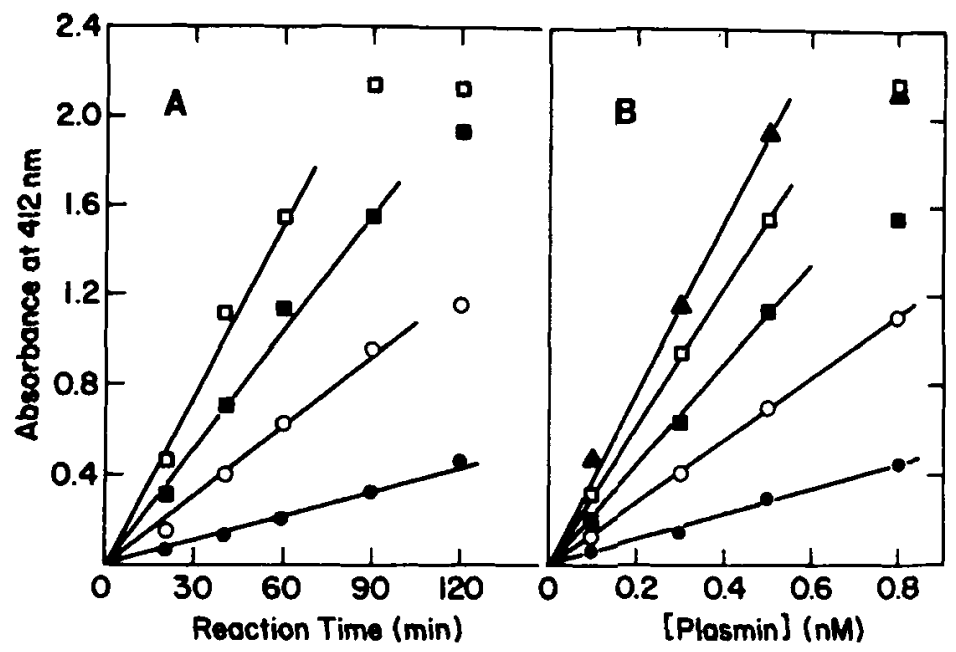

FIgure 1. The time- and plasmin concentration-dependence of $Z$-Lys-SBzl hydrolysis. A. Reactions were stopped at the time indicated by addition of soybean trypsin inhibitor. Reaction volume was $1.0 \mathrm{ml}$. [Z-Lys-SBzl] $=200 \mu M$, [DTNB] $=220$ $\mu M$. Plasmin concentrations were $0.1(O), 0.3(O), 0.5(\square)$, and $0.8(\square) \mathrm{n} M$. B. Conditions were as stated in Figure 1A. The reactions were stopped at $20(0)$, 40 (O), 60 (G), $90(\square)$, and 120 (A) min. The lines were determined by linearregression fit of the data and are drawn to encompass only the linear portion of the data. All data points represent the average of duplicates.

TABLE 2

Variations on the Standard Plasmin-Catalyzed Hydrolysis of Z-LYS-SBZL COUPLED WITH DTNB *

\begin{tabular}{lc}
\hline \multicolumn{1}{c}{ Substrate/Chromogen } & Sensitivity (A/nM) \\
\hline$Z$-Lys-SBzl/DTNB & 2000 \\
$Z$-Lys-SBzl/DTNB (2X) $\dagger$ & 2260 \\
$Z$-Lys-SBzl/2,2'-dithiodipyridine $\$$ & 700 \\
$Z$-Lys-SBzl/4,4'-dithiodipyridine $\$$ & 2030 \\
D-Val-Leu-Lys $p$-nitroanilide of & 600 \\
\hline
\end{tabular}

* Plasmin was varied $0-1 \mathrm{nM}$ in 60 min assays that were terminated by addition of $100 \mu \mathrm{l}$ soybean trypsin inhibitor as detailed in the Experimental section. DTNB reactions were measured at $412 \mathrm{~nm}$.

† Both reagents were at twice the standard concentrations.

$\ddagger$ Measured at $270 \mathrm{~nm}$, the wavelength of maximum $\Delta \mathrm{A}$.

$\$$ Measured at $324 \mathrm{~nm}$, the wavelength of maximum $\Delta A$.

$\$$ Measured at $383 \mathrm{~nm}$, the wavelength of maximum $\Delta \mathrm{A}$. 


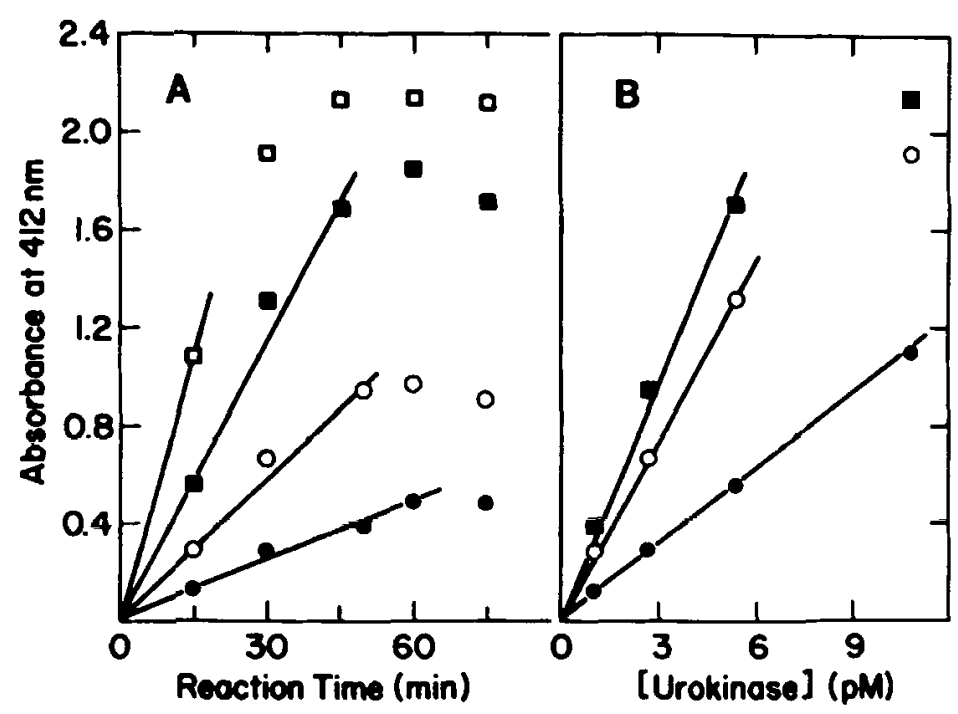

Figure 2. The time- and urokinase concentration-dependence of the plasminogen activation reaction coupled to the hydrolysis of Z-Lys-SBzl by plasmin. The conditions for the thiol ester hydrolysis are described in the Experimental section. A. The reaction was terminated at the indicated time by addition of $950 \mu \mathrm{l}$ of the plasmin reaction solution as described in the text. Urokinase concentrations were $1.08(O)$, $2.7(\mathrm{O}), 5.4(\mathbb{G})$, and 10.8 ( $\square) \mathrm{p} M$. B. Conditions were as described in FIGURE $2 \mathrm{~A}$. The activations were quenched at $15(O), 30(O)$, and $45(\mathbb{O}) \mathrm{min}$. Data at 60 and $75 \mathrm{~min}$ are not presented since the response is not a linear function beyond $45 \mathrm{~min}$ (see Figure 2A). All times and concentrations relate to the $50 \mu \mathrm{l}$ activation reaction. The lines represent a linear-regression fit of the data and are drawn to encompass only the linear portion of the data. All data points represent the average of duplicates.

These results differ significantly from those of Kettner and Shaw, ${ }^{16} 2.9 \times 10^{3}$ $\min ^{-1} \cdot \mathrm{M}^{-1}$, however the $\mathrm{pH}$ used here was 1.5 units more basic, which could account for a higher rate. Scatchard analysis of the inhibition of urokinase by the dexamethasone-induced inhibitor from HTC cells yields $K_{i} \sim 10^{-12} \mathrm{M}$, but the stoichiometry cannot be calculated because the concentration of inhibitor is unknown. A $K_{i}$ in this range has been previously reported by Green ${ }^{18}$ for the association of Kunitz pancreatic inhibitor (aprotinin) with bovine trypsin, but most protease-inhibitor complexes have lower affinities.

\section{Discussion}

In general base-catalyzed reactions, such as the "spontaneous" hydrolysis of $Z$-Lys-SBzl, the choice of buffering agent is often critical if the assay is to be used near its limit of sensitivity. The small list of buffers tested here includes a wide range of "spontaneous" rates and suggests the utility of buffer surveys as a general procedure in assay development.

The standard assay employs $1.0 \mu M$ plasminogen which is close to the $K_{m}$ concentration. An approximately two-fold increase in sensitivity would be 
realized if a ten-fold higher plasminogen concentration were used, but in most cases the higher sensitivity is not needed, and the use of $10 \mu M$ or higher substrate would consume large amounts of plasminogen.

Since there are no pure inhibitors available that are completely selective for plasminogen activators in the presence of plasmin, several other methods were used to depress the activation during the Z-Lys-SBzl step. Primarily, plasminogen activation was inhibited by dilution ( 20 -fold), but the $\mathrm{pH}$ shift (1 unit off the optimum) and the addition of chloride yielded substantial additional inhibition (two- and three-fold, respectively). The net activator activity in the second step was less than $1 \%$ of its initial value.

The sensitivity with the thiol ester compares favorably with the other substrates tested. As an ester, $Z$-Lys-SBzl has the advantage of the lowest $K_{m}$, and highest $k_{\text {cat }}$. Most of the amide substrates have high $K_{m}$ and low $k_{c a t}$ values. Their chief advantage is their chemical stability. Fluorogenic amide substrates might yield a more sensitive assay based on the greater sensitivity of detection. Were a fluorogenic thiol reagent substituted for DTNB the limit of detection of the hydrolysis of Z-Lys-SBzl might be lowered.

The spectrophotometric assay is considerably more sensitive than the radio-

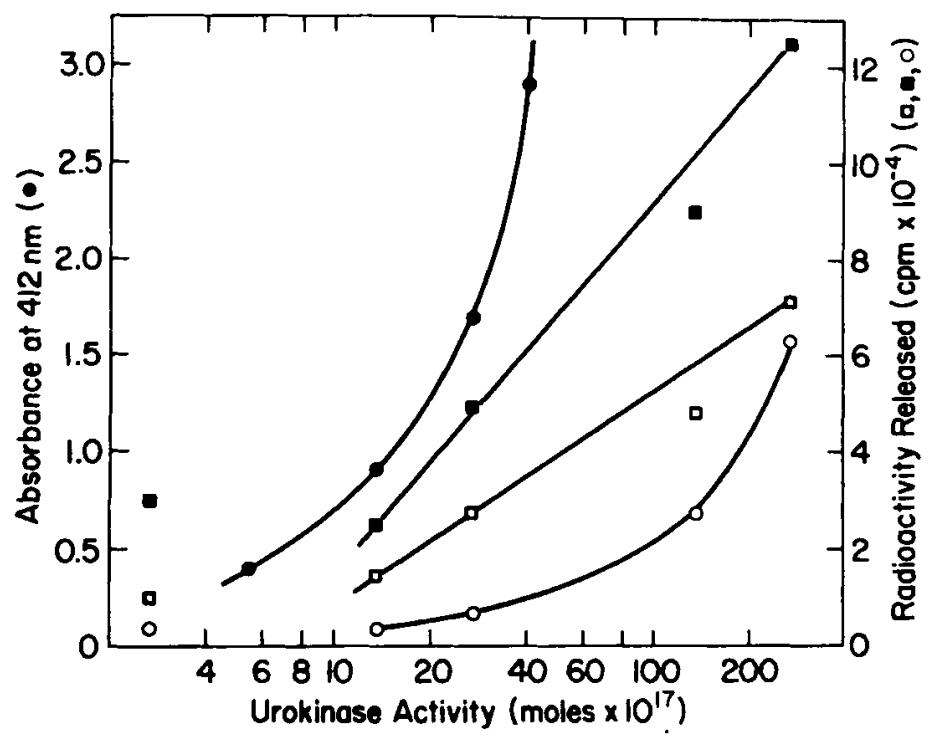

FIGURE 3. A comparison of spectrophotometric and radiometric coupled assays for urokinase. The spectrophotometric assay (O) was performed according to the standard procedures outlined in the text. The volume of continuous radiometric assay is $1.0 \mathrm{ml}$ in $100 \mathrm{mM}$ sodium glycinate, pH 8.50 with $50 \mathrm{nM}$ plasminogen. Total CPM released at $60(\square)$ and $105(\square)$ min of incubation are presented. The latter time is the total time required by the discontinuous assays. In the discontinuous radiometric assay $(O)$ plasminogen $(1.0 \mu M)$ was activated by urokinase in the glycine buffer for $45 \mathrm{~min}$ then a $50 \mu \mathrm{l}$ aliquot was added to the [ $\left.{ }^{20} \mathrm{I}\right] \mathrm{fib}$ rincoated well containing $950 \mu \mathrm{l}$ of $200 \mathrm{mM}$ sodium phosphate and $200 \mathrm{mM} \mathrm{NaCl}$. Total CPM released after $60 \mathrm{~min}$ in the presence of fibrin are presented. All reactions were perfomed at $37^{\circ} \mathrm{C}$. All radiometric points are averages of triplicates. All spectrophotometric points are averages of duplicates. 
metric assay. In the direct comparison (FIGURE 3 ) there is no difference between 2.7 and $13.5 \times 10^{-17}$ moles by the radiometric assay, whereas $\Delta \mathbf{A}_{412}$ is 0.50 between 5.4 and $13.5 \times 10^{-17}$ moles. Typically in the $Z$-Lys-SBzl assay the measured difference between $2.7 \times 10^{-17}$ moles urokinase and the zero urokinase control is $>0.100 \mathrm{~A}_{+12}$. The assay is also sensitive to other plasminogen activators. $1 \mathrm{ng}$ of protein from HeLa serum-free conditioned medium yields net $\Delta \mathrm{A}_{412}=0.190$. For $1 \mu \mathrm{g}$ of protein from HTC whole-cell extract the net $\Delta A_{412}=0.54 .20 \mathrm{ng}$ of serum-free conditioned medium protein from dexamethasone-induced HTC cells inhibits $90 \%$ of the activity present in $7 \times 10^{-16}$ moles of urokinase.

The wide versatility of the method is demonstrated by the ease of determination of $K_{m}$ and $V_{m a x}$ values for plasminogen activation and of inhibition constants for the interaction of the enzyme with natural or synthetic inhibitors. Since the assay is more rapid and sensitive to low levels of enzyme it is more readily adaptable to monitoring enzyme purification than $\left[{ }^{125} I\right]$ fibrinolysis.

In summary, the procedure is a sensitive, precise, and rapid method for the analysis and characterization of plasminogen activators. All reagents and materiais are inexpensive and commercially available, the colored products are stable, and the measurement is performed on the standard quality spectro-

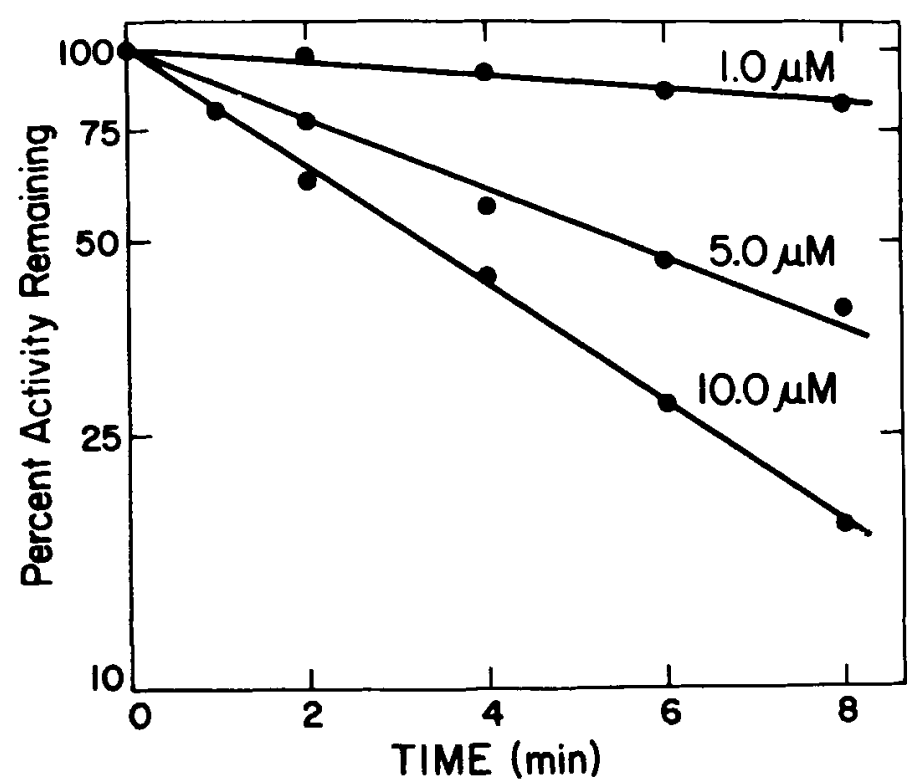

FIGURE 4. The inactivation of urokinase by $\mathrm{Phe} \cdot \mathrm{Ala} \cdot \mathrm{ArgCH} \mathrm{H}_{2} \mathrm{Cl}$. Prior to activity determination by the standard assay, urokinase $\left(1.08 \times 10^{-10} \mathrm{M}\right)$ was incubated with the indicated concentration of the tripeptidyl inhibitor in $80 \mathrm{mM}$ sodium glycinate, pH 8.50 with $1 \mathrm{mg} / \mathrm{ml}$ bovine serum albumin, $25^{\circ} \mathrm{C}$. At the indicated times, $5 \mu \mathrm{l}$ of the reaction solution were diluted into $85 \mu \mathrm{l}$ of the same glycine buffer at $0^{\circ}$. At the completion of the inactivation reaction $(8 \mathrm{~min})$ all activation reactions were initiated simultaneously by addition of $10 \mu \mathrm{l}$ of $10 \mu M$ plasminogen and removal to a $37^{\circ} \mathrm{C}$ incubator. $900 \mu \mathrm{l}$ rather than $950 \mu \mathrm{l}$ of plasmin reaction solution was used. $k_{\mathrm{npp}} /[\mathrm{I}]=260 \times 10^{3} \mathrm{~min}^{-1} \cdot \mathrm{M}^{-1}$. 


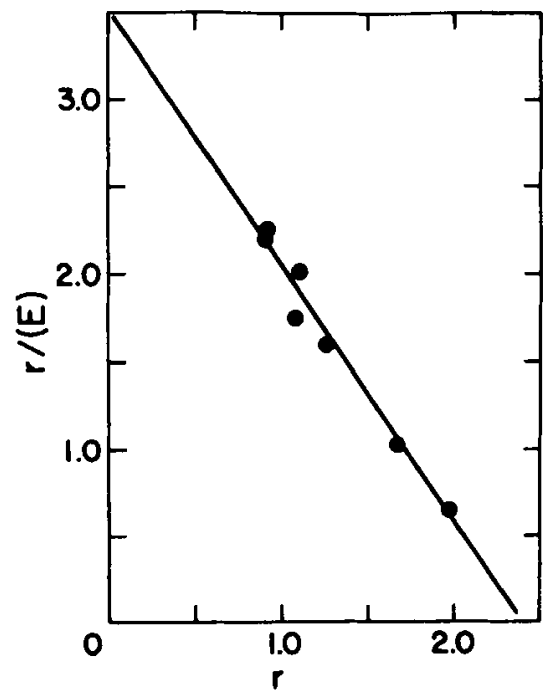

FIGURE 5. Scatchard analysis of the inhibition of urokinase by the plasminogenactivator inhibitor from hepatoma tissue-culture cells. The inhibitor test solution was the serum-free conditioned medium from dexamethasone-induced $\left(10^{-7} \mathrm{M}, 16 \mathrm{~h}\right)$ cells. $1-5 \mu \mathrm{l}$ of test solution were incubated with urokinase $\left(2.7 \times 10^{-18}\right.$ moles $)$ for 15 $\min$ at $25^{\circ}$ in $45 \mu \mathrm{l}$ total volume. The activation reaction was started by the addition of $5 \mu \mathrm{l}$ of $10 \mu \mathrm{M}$ plasminogen and shifted to $37^{\circ} \mathrm{C}$. $E$ is the concentration of active urokinase; $r$ is the concentration of inactive urokinase.

photometer available in almost all laboratories. It is superior to existing methods in its simplicity and ease of manipulation and in the quality of the resultant data--kinetic constants rather than arbitrary units.

\section{ACKNOWLEDGMENTS}

We would like to thank Dr. David Aronson (Bureau of Biologics, Public Health Service, Bethesda, MD 20014) for the gift of purified plasmin. We are also grateful to Drs. Elliott Shaw and Charles Kettner (Biology Department, Brookhaven National Laboratory, Upton, NY) for valuable discussions and the gift of Phe $\cdot \mathrm{Ala} \cdot \mathrm{ArgCH}_{2} \mathrm{Cl}$. We wish to thank Drs. Gelehrter and Sraw for financial support, encouragement, and constructive suggestions.

\section{REFERENCES}

1. Nieuwenhuizen, W., G. Wijngands \& E. Groenveld. 1977. Fluorogenic peptide amide substrates for the estimation of plasminogen activators and plasmin. Anal. Biochem. 83: 143-148.

2. Huseby, R. M., S. A. Clavin, R. E. Smith, R. N. Hull \& E. L. Smithwick, Jr. 1977. Studies on tissue culture plasminogen activator. Thrombosis Res. 10: 679-687.

3. Zimmerman, M., J. P. Quigley, B. Ashe, C. Dorn, R. Goldfarb \& W. Troll. 
1978. Direct fluorescent assay of urokinase and plasminogen activators of normal and malignant cells: kinetics and inhibitor profiles. Proc. Natl. Acad. Sci. USA 75: 750-753.

4. Wehrly, J. A. 1979. Fluorogenic detection of serine proteases: instrumentation and substrates. Ph.D. Thesis. University of Illinois. Urbana, Ill.

5. Unkeless, J. C., A. Tobin, L. Ossowski, J. P. Quigley, D. B. Rifkin \& E. REICH. 1973. An enzymatic function associated with transformation of fibroblasts by oncogenic viruses. J. Exp. Med. 137: 85-111.

6. Coleman, P., C. Kettner \& E. Shaw. 1979. Inactivation of plasminogen activator from HeLa cells by peptides of arginine chloromethyl ketone. Biochim. Biophys. Acta 569: 41-51.

7. Heussen, C. \& E. B. Dowdle. 1980. Electrophoretic analysis of plasminogen activators in polyacrylamide gels containing sodium dodecyl sulfate and copolymerized substrates. Anal. Biochem. 102: 196-202.

8. Green, G. D. J. \& E. Shaw. 1979. Thiobenzyl benzyloxycarbonyl-L-lysinate, substrate for a sensitive colorimetric assay for trypsin-like enzymes. Anal. Biochem. 93: 223-226.

9. Deutsch, D. G. \& E. T. Mertz. 1970. Plasminogen: Purification from human plasma by affinity chromatography. Science 170: 1095-1096.

10. Robbins, K. C. \& L. Summaria. 1965. Human plasminogen and plasmin. Meth. Enzymol. 19: 184-199.

11. Chase, T., JR. \& E. SHaw. 1967. p-Nitrophenyl-p'-guanidinobenzoate $\cdot \mathrm{HCl}$ : A new active site titrant for trypsin. Biochem. Biophys. Res. Commun. 29: 508-514.

12. JAmeson, G. W., D. V. Roberts, R. W. AdAms, W. S. A. Kyle \& D. T. ELMORE. 1973. Determination of operational molarity of solutions of bovine $\alpha$-chymotrypsin, trypsin, thrombin, and Factor $X_{n}$ by spectrofluorimetric titration. Biochem. J. 131: 107-117.

13. Coleman, P. L., H. G. Latham, JR. \& E. Shaw. 1976. Some sensitive methods for the assay of trypsin-like enzymes. Meth. Enzymol. 45: 12-26.

14. Siefert, S. C. \& T. D. Gelehrter. 1978. Mechanism of dexamethasone inhibition of plasminogen activator in rat hepatoma cells. Proc. Natl. Acad. Sci. USA 75: 6130-6133.

15. Riddles, P. W., R. L. Blakeley \& B. Zerner. 1979. Ellman's reagent: 5,5-dithiobis (2-nitrobenzoic acid)-a reexamination. Anal. Biochem. 94: $75-81$.

16. Kettner, C. \& E. Shaw. 1979. The susceptibility of urokinase to affinity labeling by peptides of arginine chloromethyl ketone. Biochim. Biophys. Acta 569: $31-40$.

17. Wohl, R. C., L. Summaria \& K. C. Robrins. 1980 . Kinetics of activation of human plasminogen by different activator species at $\mathrm{pH} 7.4$ and $37^{\circ} \mathrm{C}$. J. Biol. Chem. 255: 2005-2013.

18. GreEN, N. M. 1957. Kinetics of the reaction between trypsin and the pancreatic trypsin inhibitor. Biochem. J. 66: 407-415. 